\title{
Analysis of Climate Strengthening and Learning Skills through Flipped Classroom
}

\author{
Susilaningsih \\ Technology Education \\ Universitas Negeri Malang \\ Malang, Indonesia \\ susilaningsih.fip@um.ac.id \\ Eka Pramono Adi \\ Technology Education \\ Universitas Negeri Malang \\ Malang, Indonesia \\ eka.pramono.fip@um.ac.id
}

\author{
Henry Praherdhiono \\ Technology Education \\ Universitas Negeri Malang \\ Malang, Indonesia \\ henry.praherdhiono.fip@um.ac.id \\ Nunung Nindigraha \\ Technology Education \\ Universitas Negeri Malang \\ Malang, Indonesia \\ n.nindigraha@gmail.com
}

\begin{abstract}
Flipped classroom applied to learners, in order to have a learner's characteristic for the willing and skilled accomplishing the project. This ability is needed to strengthen the Self - concept and the needs of self-development of students facing the learning era. The analysis was carried out by conducting a focus group discussion between the team of researchers and developers of the Educational Technology curriculum. FGD conducted for clicking construction Upside Learning model in the study of micro-scale. The focus of analysis is 1) studies which are teachers, 2) technology and media, 3) learning contexts, 4) learning content. FGD produce models of flipped classroom a learning model that enable students to undertake exploration of learning material either online or offline under guidance before giving substance subjects. Substance is carried out at meetings in class.
\end{abstract}

Keywords-learner's characteristic, self-concept, life-based learning, flipped classroom

\section{INTRODUCTION}

Learning innovation is needed to improve student capabilities. The capabilities needed in the Industrial 4.0 era are students who are creative, innovative and anticipatory. Some studies of construction models Upside Learning is a learning model where students learn through exploration of learning material on-line before the meeting in the classroom. Cognitive reinforcement at the beginning before class meeting can 1) motivate students towards active learning, 2) improve high-level thinking skills, and 3) improve collaborative skills [1].

Chronology of the pedagogical system in general is putting cognitive reinforcement face-to-face before students are given assignments online. The research is generally carried out for students with adult age. The need for efforts to develop students at the junior high school level. So that learning material both on-line and online from various learning sources can be used independently for middle-aged children. As far as researchers, application of learning online and offline at junior level has not been a major activity in learning.

The inverse learning paradigm is constructivism. The success of learning is not only determined by learning outcomes, but the desire or willingness to continue learning so that it becomes a skilled learner is also a learning success. Several studies were conducted to build student knowledge before class meetings were held. Research develops classroom lecture activities and provides videos online so students can watch and review teaching content more easily [2. With such a strategy, significant results are obtained, which inspire them to use it further (for example, studying through online video) in front of the class. With this way, the student prepares knowledge in class by watching the video shown. Learning that is independent has formed the basic knowledge of students. Strengthening by researchers is generally deeper discussion or training in the classroom. The results obtained by several studies generally increase the involvement of students in deeper learning and help them clarify any misunderstandings [2].

Life-based learning through reverse learning methods proposes a learning framework for developing student capabilities in willing and collaborating as a characteristic of students' abilities. Learning is not limited to competency but requires the development of student capabilities which are concrete in the form of student characters. Life-Based Learning recognizes that the living environment becomes a very broad learning resource, thus opening opportunities for students who have initiatives and collaborate with anyone to develop their capabilities.

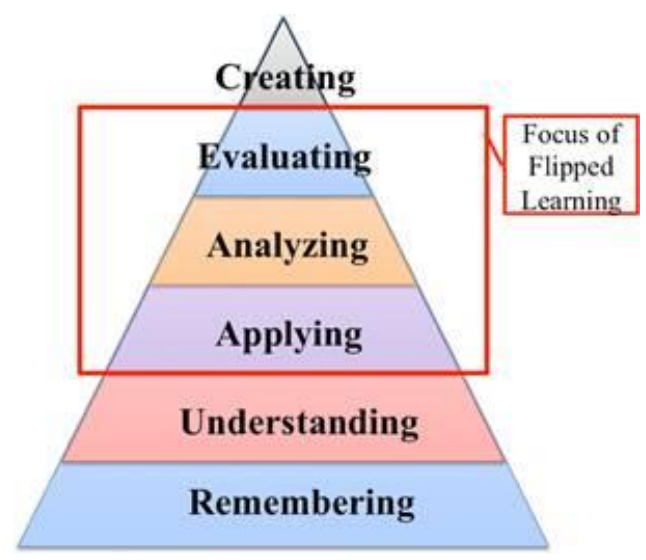


Fig. 1. Purpose of learning inverse class activities

The educational objectives of reverse learning can be overcome based on the educational objective taxonomy proposed by Bloom and modified by Anderson et al. [3]. There are six levels: knowledge, understanding, application, analysis, synthesis, and evaluation. As shown in Figure 1, in reversing learning, what students do before and after class is included in remembering and understanding, namely lower cognitive levels. Video instructions are used to express the basic contents of the target subject. In class, higher levels of cognitive learning are cultivated, such as application, analysis, and evaluation [4].

The inverted learning construction model is very relevant to the integration policy of learning management technology in the network of Malang State University Laboratory Schools. The management of learning in the network The Laboratory School of Malang State University currently in principle has met the standards of general pedagogy and has been in accordance with the requirements of the Life-Based Learning environment. So that it has the potential to have empirical support to bring a new perspective of students to the world of initiative so that they can develop their life skills. In harmony with Higgins [5] is the level of integration of class technology combined with a pedagogical system so that alignment with the learning style that students like will encourage student capability. Students need sufficient and open scientific insight to have the will in the form of initiative to act and as a provision for constructing science through collaboration with teachers and other students. This will not be realized if the pedagogical system at the beginning of learning is still in the form of giving transfer or copying the mindset through class meetings which are explanatory, definitive, doctrinal or otherwise.

In the process of willing students need to be supported by their logical thinking patterns. do Vale et al. explains that children's development begins to be able to think logically is at the stage of formal operations, namely at the age of 12 years and above [6]. Bandura describes the socio-cognitive development of adolescents starting to be able to organize and assess themselves [7], [8]. With this foundation why the research subject is junior high school students.

\section{METHOD}

The focus of the Group Discussion was carried out with several experts in charge of the curriculum, learning and learning resources. The Analysis Method includes several focuses, namely:

\section{1) Audience Analysis (teacher),}

Analysis is used to describe student targets. The analysis also provides a description in the context of the student population,

\section{2) Analysis of technology and media,}

A technology analysis describes the technology for developing management systems for reverse pedagogical models which are technologies related to hardware, software and their interconnections. Analyzing the media described in the media used in learning. Description includes learning object -based text, image, audio, video and web,

\section{3) Analysis of situation (context),}

This analysis describe the environment in which the model will be implemented reverse pedagogy and the characteristics of the learning environment itself.

\section{4) Objective analysis (content),}

This analysis describes learning objects that will be used in reverse pedagogy models

\section{RESULT AND DISCUSSION}

The development of learning to construct the student's skills junior lab in learning through learning the art of inverted self-concept in wills produce the analysis as follows:

\section{1) Analysis of the audience (teachers),}

General school teachers Malang State University Laboratory has been teaching on subjects in accordance with their respective competence. All teachers of Malang State University Laboratory Middle School have a degree or a minimum of S1. So, personally, the teacher of Malang State University Laboratory Middle School can be developed professionally. Needs to be the foundation is p Enhancing the quality of the teachers of SMP Laboratory of University of Malang is an important thing to do, $\mathrm{k}$ arena as well as any curriculum 2013 which has been planned to be implemented, will not work well without the support of teachers who have quality. In general, some things that cause less quality, including:

- Non-conformity of disciplines with teaching fields.

The field of art is a complex field in the aspect of learning. Art and culture are a series of knowledge, attitudes and skills. Art teacher and culture of SMP Laboratory of the State University of Malang have obligation to teach the material culture and art as a whole for the purpose of cultural artistic subjects not only partially achieved. In general there are no colleges that pass complex knowledge, attitudes and skills for fine arts, music, dance, drama, and art life. Higher education produces only teachers of fine arts education (partial). This causes teacher quality to require attention. $\mathrm{S}$ is a cultural arts teacher at the State University of Malang Laboratory demanded to master the concept of cultural arts subjects as a whole is a complex workload

- Low professionalism in teachers.

Self-development is not an easy job. The teacher's self-development is a complex job so that the State University Malang Junior High School Laboratory teachers are generally still reluctant to develop themselves to increase their 
knowledge and competence in teaching. Classroom action research is still a discourse that is always collided with reasons for administrative busyness (24 hours per week learning hours, professional administration as a demand for education services and other reasons).

\section{2) Technology and media analysis.}

The use of learning technology has been fixed in the 2013 curriculum. This suggests that learning technology has shifted from science to bureaucratic consumption. In general, learning technology does not only complete training and homework. But learning technology has developed more humanist and even leads to a constructivism paradigm. But generally speaking, learning technology with a scientific approach is the only technology that is believed to solve problems. Technology and learning media are not well developed as well as technology and learning media in educational technology. The development of technology and learning media has led to the use of classrooms, libraries, open learning resources as a place to dig deeper into what they have learned. Whether or not the technology is realized is not yet the main one. Technology and learning media still lead to reading sources provided by the government and private publishers.

Technology and learning media need to be directed towards reverse pedagogy. Technology and learning media need to facilitate video lectures, demonstration videos and practices until complete reading can be accessed anywhere including at home and school. So that the work of accessing learning resources will be equipped with an explanation of what students do not understand in the next phase. Reverse pedagogy technology is a science that is very foreign to teachers at Malang State University Laboratory Middle School. Whereas the technological and media potential in reverse pedagogy leads to strengthening collaborating with information to answer questions, complete projects and carry out other activities that are usually provided as homework. Technology and media at this time have not led to the allocation of time to help students with content that they do not understand.

\section{3) Situation Analysis.}

In general, the existence of Malang State University Junior High School cannot be said to be a beginner school. This is because this school has been established since 1990 with the name of SMP IKIP Malang under the auspices of the Bhinneka Karya educational foundation unit of the KORPRI IKIP Malang. In 1996 the unfortunate work of various foundations changed its name to the poor IKIP education foundation, in 2005/2006 there was another change of name from poor IKIP junior high school under the auspices of the IKIP MALANG educational foundation to become a Laboratory Middle State University of Malang under the auspices of the Malang State University education foundation ( YPUM) Development of teaching technology at Malang State University Laboratory Middle School is not the first technology development, this is because Malang State University Laboratory Middle School uses a module system and acceleration / acceleration until now the module system is still running even though there are few obstacles experienced by students.

The dynamics of bureaucratic development are carried out based on changes in the foundation of the foundation's work. In 2009 precisely on 15 October 2009 the Education Foundation of Malang State University (YPUM) was merged with the Laboratory School Development Unit (UPSL) of the State University of Malang to become the Educational Laboratory Development Agency (BPLP) of the State University of Malang. From year to year, the Laboratory State University of Malang always experiences an increase, this is evident from the number of students who are always increasing in each school year, because junior high school state universities are poorly located strategically and in various types of vehicles/public transportation.

SMP Malang State Laboratory experienced developments in academics, facilities and infrastructure. The academic year 2011/2012 the number of students reached 567 students grouped into 18 class learning classes with details of 15 regular classes and 3 ICP classes (international Cambridge program) taught by 36 teachers who are competent in their field and assisted by 10 administrative staff. In 2013 namely the 2012/2013 school year, the number of students reached 608 students which were grouped into 20 classes of learning classes with details of 16 regular classes, 1 acceleration class. While the 2013/2014 school year the number of students reached 772 students grouped into 22 classes. Taught by 39 teachers who are competent in their field (including 6 teachers with S2 qualifications, 1 teacher is currently studying S2) and assisted by 4 administrative staff, 4 cleaning staff, and 4 security guards. 2014/2015 school year the number of students reached 724 students grouped into 23 classes. Taught by 41 teachers who are competent in their fields (including 6 teachers with S2 qualifications, 1 teacher is currently studying S2) and assisted by 4 administrative staff, 4 cleaning staff, and 4 security guards. With academic construction, facilities and infrastructure at the State Laboratory of Malang State University have the ability to be developed.

In the 2010/2011 school year, the State Laboratory of Malang State University was trusted by the Malang City Education Office as a private school that organizes inclusion classes. Until 2013/2014, there were 10 students with special needs (ABK) (2 grade 9 students, 4 8th grade students and 4 7th graders) accompanied by 6 special mentoring teachers (GPK). While for acceleration or CIBI programs (special idiosyncratic talents), Malang State University Laboratory Middle School was given permission to hold an acceleration program from any other foundation, for permission from the city education department was still in process.

Academic year 2012/2013, State Laboratory of Malang State Junior High School graduated ten first generation acceleration students. Besides academic activities, students can also develop their talents and interests in Malang State University Junior High School which are channeled through school extracurricular activities. Extracurricular activities include: scouts (extra compulsory for 7th graders), arts (dance and music), futsal, basketball, PMR, BDI, ECC, mading, drum-band, and karawitan. In order to support the 
improvement of the quality of learning, the Laboratory State University of Malang has a computer laboratory, language laboratory, IPA laboratory, office room, auxiliary room, inclusion room, supporting library space, music room, cooking room and its own sports field (futsal, basketball and volley, long jump and high jump). Step by step in developments tailored to the needs, up to now there has also been a canteen room with a capacity of six sales booths (in addition to student cooperatives, has been developed for a long time), 1 room for inclusion, security posts, mosques that can accommodate all students for Dhuha prayer, Dhuhur prayers, Ashar prayers and Friday prayers, and 7 gazebo that can be used for outdoor learning activities.

In the 2010/2011 school year Malang State University Laboratory Middle School received life skill equipment, in the form of 3 computer units, 1 scanner unit and 5 units of drawing equipment. These tools are used for making animation skills. At the end of the 2010/2011 school year, Malang State University Laboratory Middle School received assistance from the national education office of Malang City to receive a scanner for help in correcting students' answer sheets (LJK).

For the 2012/2013 school year through 2013/2014, three out of four proposals for proposals to the poor city education ministry were accepted, including ips props, mathematics and sports. While for inclusion programs, junior high schools receive e-learning grants and all students get scholarships from class (special education and special services) under the directorate general of secondary education in Jakarta.

In accordance with BPPP policy and um, in 2016 the acceptance of ICP class (International Class Program) was transferred from international junior high school lab to Malang State Laboratory Middle School and will continue in 2017. Thus the international junior high school lab lives to continue class 9 . So, on so that the next 2 years all ICP classes are all managed by the State University of Malang Laboratory Middle School. This policy is taken with the hope that the ICP class will be integrated from SD, SMP to SMA. Thus this ICP class can be used as a reference for other educational institutions that want to study to UM.

At this time, Malang State University Laboratory Middle School has 23 units with details of class 7 as many as 8 regular program classes and 1 ICP class, 7 classes as many as 7 classes, and grade 9 as many as 7 classes. The number of students currently is 739 people with details of class 7 as many as 280 people (254 regular and 26 ICP), class 8 as many as 222 people, and class 9 as many as 237 people. The number of teachers is 38 people and employees are 12 people with details of 4 administrative staff, 4 cleaning staff, and 4 security personnel.

\section{4) Objective Analysis (content),}

If we look at the objectives of learning arts and culture in junior high schools and the example of a complete cultural arts syllabus, we will find four dimensions of the objectives of learning art and culture, namely:

1. Students can understand and understand the concepts and importance of cultural arts

\section{Students can show an appreciation for art}

3. Students can show creativity through cultural arts

4. Students can demonstrate their participation in the development of cultural arts at the local, regional and global levels.

Objectives of Cultural Arts Subjects. The subject of Cultural Arts and Skills aims to have students as follows.

1. Understand the concepts and importance of cultural arts and skills

2. Showing an attitude of appreciation for cultural arts and skills

3. Showing creativity through cultural arts and skills

4. Showing participation in cultural arts and skills at the local, regional and global level.

Scope of Subjects in Cultural Arts The subjects of Cultural Arts and Skills include the following aspects.

1. Fine art, including knowledge, skills, and values in producing works of art in the form of paintings, sculptures, carvings, printing, and so on

2. Music art, including the ability to master vocal, playing musical instruments, appreciation of musical works

3. Dance includes movement skills based on body work with and without sound stimuli, appreciation of dance movements

4. Performing arts, including performance skills by combining music, dance and roles

5. Skills, covering all aspects of life skills which include personal skills, social skills, vocational skills and academic skills.

Cultural Arts subjects include the following aspects: 1) Fine arts, including knowledge, skills, and values in producing works of art in the form of painting, sculpture, carving, printing, and so on. 2) Music art, including the ability to master vocal, play musical instruments, appreciation of musical works. 3) Dance, including movement skills based on body work with and without sound stimuli, appreciation of dance movements. 4) Theatre 0 arts, including bodybuilding, thought processing, and sound processing skills that combine elements of art music, dance and acting.

\section{CONCLUSION}

General research to construct the Reverse Learning model so that students have the Learner's characteristic will and skill in collaborating as a form of self-concept and students' self-development needs in art learning. So that it can be used as a foundation in implementing learning using technology integration in learning art in junior high schools. The construction of the inverted learning model is the learning and learning construction needed in the micro scale of the application of life-based learning or the macro curriculum of the Malang University Laboratory School. Inverted Learning Model needs to be constructed so 
that in detail it can be applied to all units including LAB schools in developing the student's characteristic characteristics as life-based learning outcomes. The inverted learning model will contribute to the concrete realization of the development of student characters that are compatible with life-based learning that can be accounted for empirically.

\section{REFERENCES}

[1] Dagen, AS, \& Morewood, A. (2016). Strengthening Early Literacy Through Online Collaboration and Mentoring. YC Young Children $71(4), 20$.

[2] Bergmann, J., \& Sams, A. (2012). Flip your classroom: Reach every student in every class every day. International Society for Technology in Education.

[3] Anderson, LW, Krathwohl, DR, Airasian, P., Cruikshank, K., Mayer, R., Pintrich, P., ... Wittrock, M. (2001). A taxonomy for learning, teaching and assessing: A revision of Bloom's taxonomy. New York.
Longman Publishing. Artz, AF, \& Armor-Thomas, E. (1992). Development of a Cognitive Metacognitive Framework for Protocol Analysis of Mathematical Problem Solving in Small Groups. Cognition and Instruction , 9 (2), 137-175.

[4] Francl, TJ (2014). Is Flipped Learning Appropriate? Journal of Research in Innovative Teaching , 7 (1).

[5] Higgins, S. (2016). New (and Old) Technologies for Learning: Innovation and Educational Growth.

[6] do Vale, S., Selinger, L., Martins, JM, Bicho, M., do Carmo, I., \& Escera, C. (2016). Hormonal modulation of novelty processing in women: Enhanced under working memory load with high dehydroepiandrosterone-sulfate-to-dehydroepiandrosterone ratios. Neuroscience Letters , 634 , 98-103.

[7] Bandura, A. (1989). Human agency in social cognitive theory. American Psychologist , 44 (9), 1175.

[8] Bandura, A. (1991). Social cognitive theory of self-regulation. Organizational Behavior and Human Decision Processes , 50 (2), $248-287$. 